\title{
CRYSTALLOGRAPHIC STRUCTURE OF POLYGRYSTALLINE ICE
}

\author{
By M. Matsuda and G. Wakahama \\ (Institute of Low Temperature Science, Hokkaido University, Sapporo, Japan o6o)
}

\begin{abstract}
For several types of polycrystalline ice of different origins, the spatial lattice orientation of each crystal was determined by measurements of both the $a$ - and $c$-axis orientations. Analyses of the orientations of adjoining crystals showed that a great majority of adjoining crystals may be in a twinning relation. With special reference to the multi-maximum $c$-axis preferred-orientation fabric (the so-called "diamond pattern"), which is expected to occupy the largest part of a glacier ice mass, the crystal boundary structure was estimated. The preferred $c$-axis orientations of this fabric were explained as being the result of coincident oxygen-oxygen lines (hydrogen-bond lines) between adjoining crystals being concentrated in the orientations where seven oxygen-oxygen lines of one single crystal of ice are distributed. From the above result, it was concluded that the multi-maximum fabric is of the polycrystalline structure closest to the structure of a single crystal of ice among all the fabrics found in large ice masses.

It is found that the occurrence, in glaciers and ice sheets, of a multi-maximum fabric has a bias to the parts which have undergone a strong shear deformation for a long time. It is thus suggested that plastic deformation of ice with this fabric may be attributed to mechanical twinning due to a strong shear stress.

RÉsumé. Structure cristallographique de la glace polycristalline. On détermine l'orientation spatiale du réseau cristallin de chaque grain par repérage des axes $a$ et $c$ pour divers types de glace polycristalline de diverses origines. L'analyse des orientations des cristaux adjacents met en évidence qu'une grande majorité de cristaux adjacents pourrait être en relation de macle. En se référant plus particulièrement à la texture d'orientation avec une figure de pôle relative à l'axe $c$ à plusieurs maxima (généralement désigné: type diamant), que l'on s'attache à trouver dans la plus grande partie des glaciers, on a pu déduire un mode d'association des grains. L'orientation préférentielle de l'axe $c$ de cette texture a été expliquée par le fait que les directions passant par deux oxygènes voisins (liaison hydrogène) dans le cas de cristaux adjacents se concentrent vers les orientations des sept axes oxygène-oxygène rencontrés dans le monocristal. A partir des résultats précédents, on peut conclure que la texture à plusieurs maxima est celle des structures polycristallines qui se rapprochent le plus de la structure d'un monocristal parmi toutes les textures trouvées dans un glacier.

Nous avons observé que l'apparition, dans les glaciers et les couverts de glace, d'une texture à plusieurs
\end{abstract} maxima est corrélée avec l'existence d'une déformation en cisaillement importante effectuée pendant des temps longs. Nous suggérons alors que la déformation plastique des glaces présentant une telle texture pourrait résulter d'un phénomène de maclage sous l'effet de contraintes de cisaillement élevées.

Zusammenfassung. Kristallographische Struktur polykristallinen Eises. Für mehrere Arten polykristallinen Eises verschiedener Herkunft wurde die räumliche Gitterorientierung eines jeden Kristalls durch Messung $\operatorname{der} a$ - und $c$-Achsenausrichtung bestimmt. Untersuchung der Ausrichtungen benachbarter Kristalle machten klar, dass eine grosse Mehrheit aneinander angrenzender Kristalle in einer Zwillingsbeziehung stehen könnte. Die Kristallkorngrenzenstruktur wurde abgeschätzt mit besonderer Berücksichtigung des Gefüges mit Vielfachmaxima der $c$-Achsenrichtung (sogenanntes "Diamantmuster"), von dem man annimmt dass es den grössten Teil einer Gletschermasse einnimmt. Die bevorzugte $c$-Achsenausrichtung dieses Gefüges wurde als Ergebnis der Tatsache gedeutet, dass die zusammenfallenden Sauerstoff-SauerstoffLinien (Wasserstoff brückenbindungslinien) zwischen angrenzenden Kristallen sich auf die Richtungen konzentrieren, in denen sich sieben Sauerstoff-Sauerstoff-Linien eines Eis-Einkristalles aufteilen. Aus den obigen Ergebnissen wurde geschlossen, dass unter all den Gefügen, die in grossen Eismassen gefunden werden, das Vielfachmaximumgefüge diejenige polykristalline Struktur ist, die der Struktur eines EisEinkristalls am nächsten kommt.

Es wurde gefunden, dass das Vielfachmaximumgefüge in Gletschern und Eisschilden vorzugsweise in denjenigen Teilen auftritt, die lange eine starke Schubverformung erfahren haben. Es liegt daher nahe, dass eine plastische Verformung von Eis mit diesem Gefüge, der mechanischen Zwillingsbildung aufgrund einer starken Schubspannung zugeschrieben werden kann.

\section{Introduction}

In order to study the relationships between the crystallographic orientations of adjoining crystals, measurements were made of the orientations of all three $a$-axes and the $c$-axis of each crystal in a polycrystalline ice, since measurements not only of $c$-axis but also of $a$-axis orientations are necessary for a full determination of the lattice orientation. The ice samples used had different origins: ice from the Antarctic ice sheet, ice from polar and temperate glaciers, commercial ice, and home-made ice. 
For the $c$-axis, the measurements disclosed preferred orientation fabrics such as singlemaximum, multi-maximum, and girdle fabrics. With special reference to the multi-maximum fabric, that is, the so-called "diamond pattern", a twinning explanation was proposed for the preferred orientations on the basis of the $a$-axis measurements.

A number of fabrics of $c$-axis preferred orientations have been reported since a comprehensive study by Rigsby (I95I) on glacier ice, and such orientations and their relations with the fabrics have been subjects of major interest in ice fabric studies. Hence, experimental and theoretical work has been extensively devoted to the clarification of the mechanism of fabric formation (Kamb, I959[a], [b], I972; Rigsby, r960, r968; Brace, r960; MacDonald, I96o; Kumazawa, I963; Watanabe and Oura, I968; Kizaki, I969[a], [b], I974; Jonsson, I970; Tanaka, 1972; Budd, I972; Budd and Matsuda, 1974; Matsuda and others, 1976). While
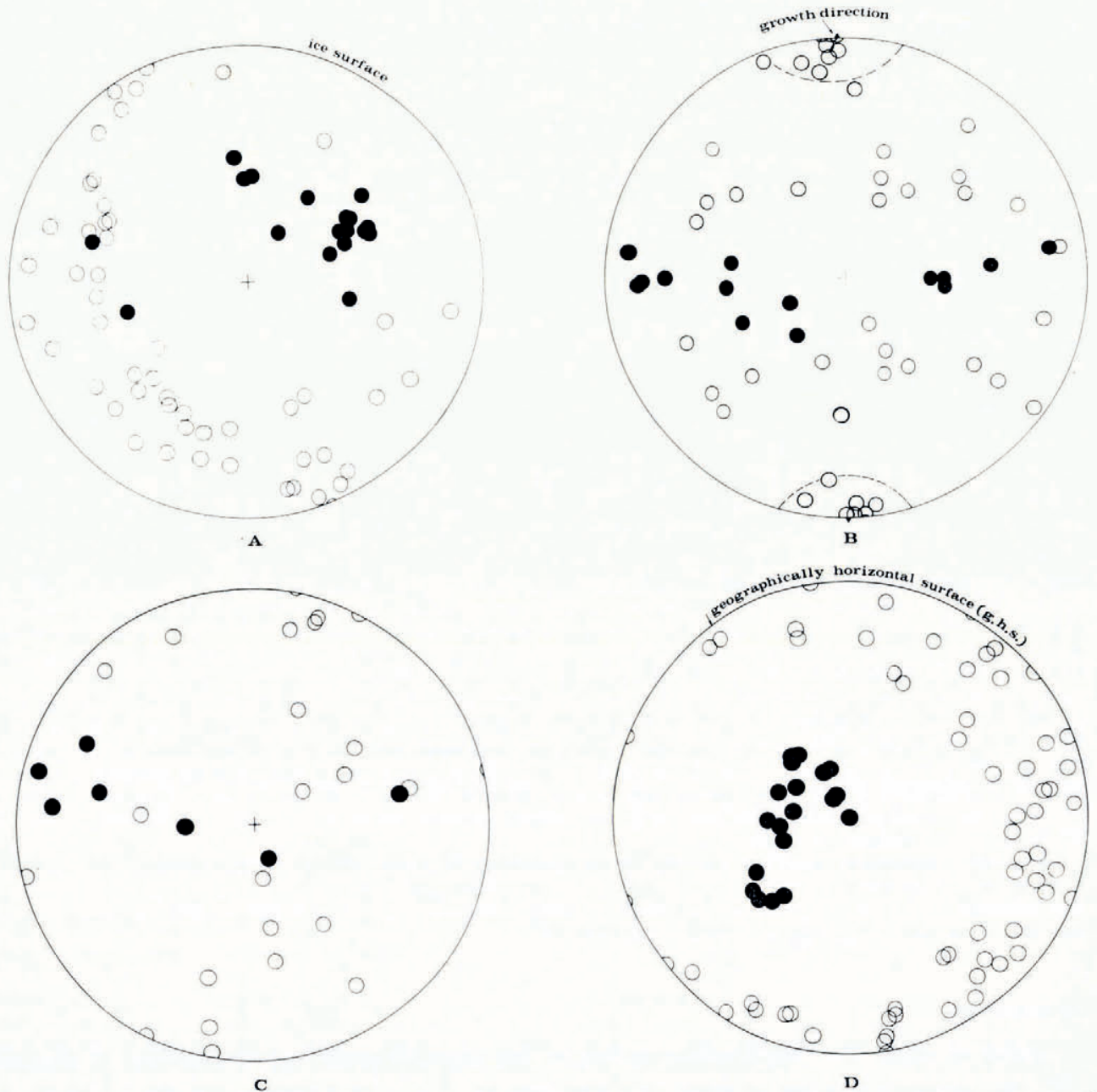

Fig. I. Fabric diagram of orientations of both c-axes (solid symbols) and a-axes (open symbols), plotted on an equal-area Schmidt net. Polycrystalline ice samples are designated as follows. A: Thin ice made in a laboratory dish. B: Candle ice grown unilaterally from randomly oriented snow crystals in a laboratory. C: Commercial ice. D: "Byrd" station core ice in Antartic ice sheet (I 689 $\mathrm{m}$ depth). E: "Byrd" station core ice (2 $003 \mathrm{~m}$ depth). F: Cape Folger core ice in Antarctic ice sheet $(259 \mathrm{~m}$ depth). G: Mendenhall Glacier ice, Alaska, collected on the surface, $2.5 \mathrm{~km}$ up-stream from the glacier terminus. 
theoretical approaches were mainly based on the thermodynamic equilibrium of ice crystals, the fabric formation has not yet been explained well enough, probably because crystalographic orientations of a polycrystalline ice have been measured so far only for the $c$-axis without taking the $a$-axis orientation into account.

\section{Preferred orientations of $c$ - And $a$-AXes}

Crystallographic orientations of both the $c$ - and $a$-axes were measured by a universal stage, using an etch-pit technique. The detailed procedure will be described in a paper in preparation.* Orientations of the $c$-axis and $a$-axes of all the crystals in a thin section were plotted on an equal-area projection net (Schmidt net) with solid symbols ( $c$-axes) and open symbols ( $a$-axes) (A, B, C, D, E, F, and G in Fig. I).
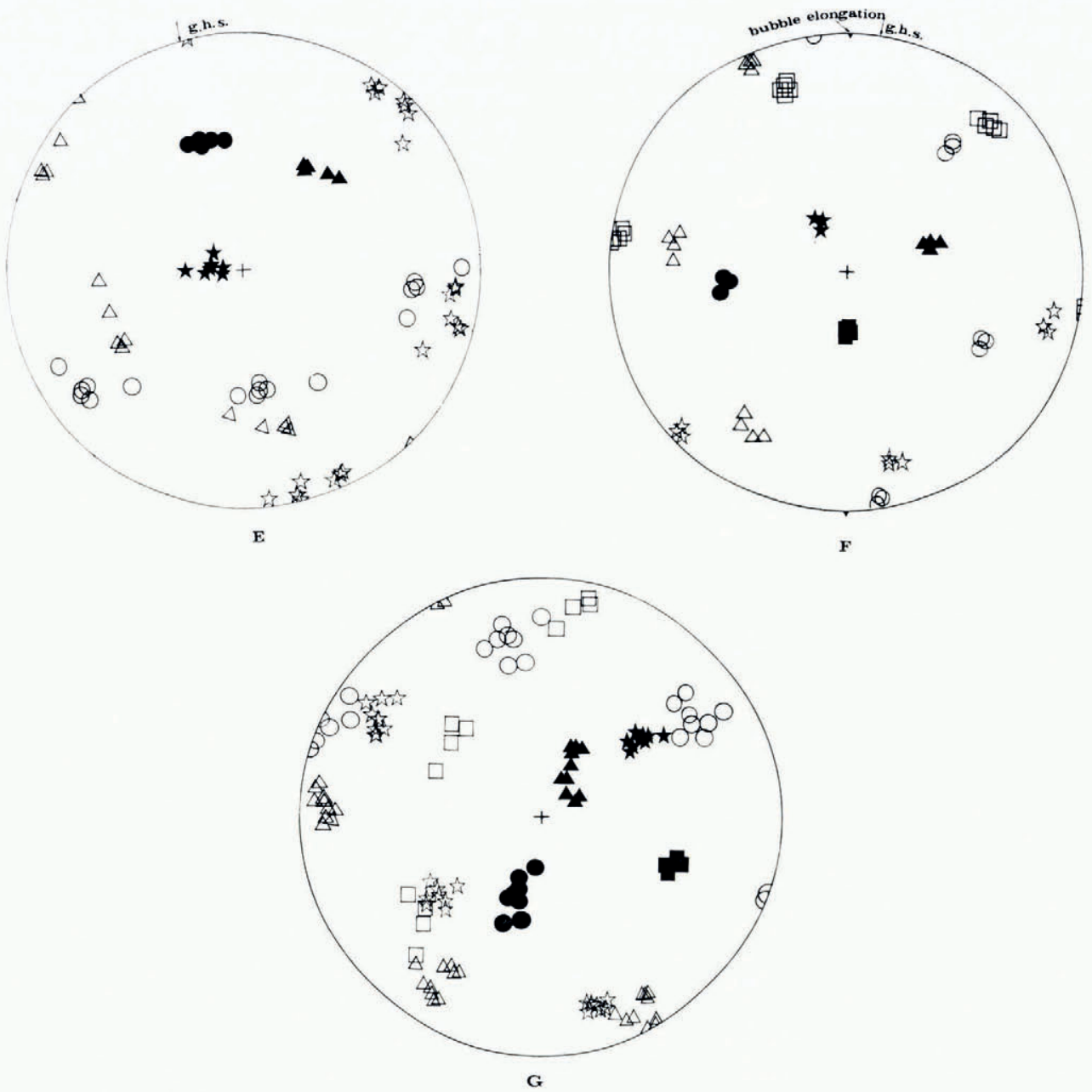

Fig. I.

* Paper in preparation by M. Matsuda entitled "Determination of $a$-axis orientations in polycrystalline ice". 
Both a thin ice (A) made in a laboratory dish from a melt and a commercial ice (C) do not have strong preferred orientations of $a$ - and $c$-axes. However, a candle ice (в) shows a girdle fabric of $c$-axis orientations. This candle ice was made in the laboratory from crushed small snow crystals, which were scattered on a water surface kept at the freezing temperature, and grew downward unilaterally. All the $c$-axes are roughly parallel to the freezing surface and one out of the three $a$-axes of each crystal concentrates in the growth direction (surrounded by a dashed circle). This may result from the difference of growth rates in that snow crystals with one of the three $a$-axes initially oriented in the growth direction grew faster than those with three $a$-axes oriented obliquely.

A "Byrd" core ice (D) shows a typical single-maximum fabric in which $c$-axes concentrate on one small area, whereas $a$-axes do not. Although the ice with this fabric appears to have the polycrystalline structure closest to the structure of a single crystal of ice, it is recognized that most of the crystals are actually in very different crystallographic orientations from each other as far as the $a$-axis orientation is concerned. A "Byrd" core ice (E), a Cape Folger core ice (F), and a Mendenhall Glacier ice (G) show the typical multi-maximum fabric of $c$-axis orientations. This "diamond pattern" has been reported to exist in many glaciers and the Antarctic ice sheet as well (Kamb, I959[a], [b]; Rigsby, I96o; Kizaki, I962, I969[b]; Taylor, I963; Reid, r964; Higashi, I967; Gow, I970; Jonsson, r970; Endō, I97 I; Budd, I972; Hooke, I973; Vallon and others, 1976; Matsuda and others, 1976, and a paper in preparation*). It is expected from its occurrence that the ice of this fabric occupies the lower part near the bed of an accumulation area, and the major part of an ablation area. This implies that a strong pressure applied for a long time at near-melting temperature contributes to the formation of this fabric. Ice crystals with this fabric which have the same $c$-axis orientations (indicated by the same symbols) have each of their $a$-axes (indicated by open but the same symbols as their $c$-axes) also nearly in the same orientations. Although all the crystals in the same $c$-axis orientation plotted in Figure $\mathrm{I}$ are apparently located separately in a two-dimensional thin section, they appear to represent the parts of a large single ice crystal connected in the third dimension.

It should be noted that, as far as the number of crystals in different crystallographic orientations is concerned, the polycrystalline ice closest to a single crystal is not that with the single-maximum $c$-axis fabric, but one with a multi-maximum $c$-axis fabric.

The multi-maximum fabric is expected to occupy the largest part of a glacier ice mass and is consequently of the greatest importance to investigate. Matsuda and others (1977) examined the crystal shape of a sample of Cape Folger core ice as a typical example of this fabric. They concluded that all crystals having the same crystallographic orientation may be interconnected outside the thin section to be a large single crystal of ice, and thus multimaximum fabric ice is composed of a very small number of extremely large network-like ice crystals.

\section{Twinning of ICE}

The measurement of both $a$ - and $c$-axis orientation of an ice crystal gives the full spatial lattice orientation, making it possible to shed light on relationships between adjoining crystals. A pair of adjoining crystals in any orientation of the hexagonal crystal system have twelve possible rotations by which the two lattices become congruent or enantiomorphous (International Union of Crystallography, I959, p. 104). There is a relationship between the rotation angle $\tau$, the angle $\gamma$ between the $c$-axes of the adjoining crystals, and the angle $\alpha_{i j}$

\footnotetext{
ice".

* Paper in preparation by M. Matsuda, G. Wakahama, and W. F. Budd entitled "Twinning of Antarctic
} 
related to the $a$-axis (shown in Figure 2) which can be derived using simple spherical trigonometry (Fig. 2):

$$
\sin ^{2}\left(\frac{1}{2} \tau\right)=\sin ^{2}\left(\frac{1}{2} \gamma\right)+\cos ^{2}\left(\frac{1}{2} \gamma\right) \sin ^{2} \alpha_{i j},
$$

where $\alpha_{i j}=\frac{1}{2}\left(\alpha_{i}+\alpha_{j}{ }^{\prime}\right) \quad(i, j=\mathrm{I}, 2$, or 3$)$. The angles $\alpha_{i}$ and $\alpha_{j}{ }^{\prime}$ must be measured so that $\alpha_{i j} \leqslant 90^{\circ}$. Thus, there can be six combinations of the value $\alpha_{i j}$ needing to be taken into account for a given angle $\gamma$.

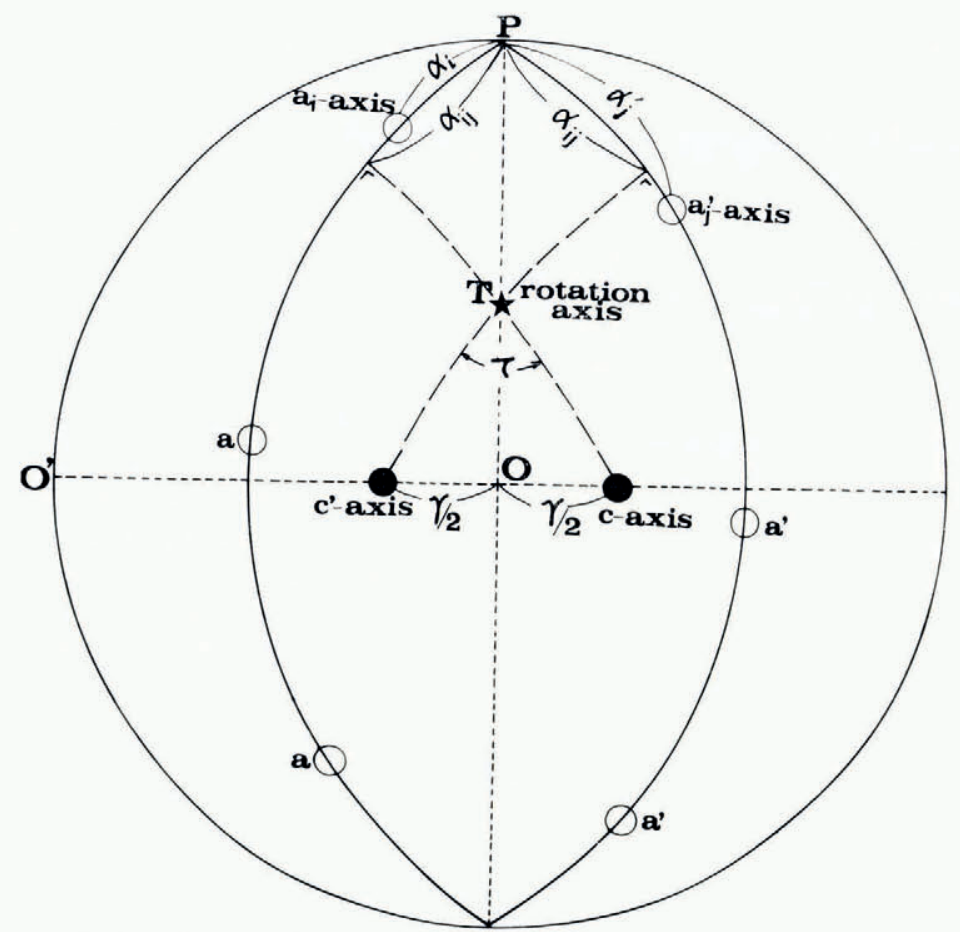

Fig. 2. Crystal relationship of a pair of adjoining crystals plotted on a Wulff net. $c\left(c^{\prime}\right): c$-axis, a $\left(a^{\prime}\right):$ a-axis, $P$ : intersection between two basal planes of adjoining crystals, $\alpha_{i}\left(\alpha_{j}^{\prime}\right)$ : angle between $a_{i}\left(a_{j}^{\prime}\right)$ and $\dot{P}, T:$ rotation axis, $\tau$ : rotation angle, $\gamma$ : angle between $c$ and $c^{\prime}$.

For all the measured pairs of adjoining ice crystals, the angles $\alpha_{i}, \alpha_{j}{ }^{\prime}$, and $\gamma$ and its supplementary angle were obtained, from which the twelve rotation angles $\tau$ were calculated. After a careful inspection of the twinning law, the rotation angle closest to one of $60^{\circ}, 90^{\circ}, 120^{\circ}$, or $180^{\circ}$ was chosen and plotted on a $\gamma-\alpha_{i j}-\tau$ diagram (Fig. 3).

The diagram shows that more than eighty per cent of all the pairs of adjoining crystals have at least one of the rotation angles, $60^{\circ}, 90^{\circ}, 120^{\circ}$, and $180^{\circ}$ with an accuracy of $\pm 2^{\circ}$, and that about a half of all the pairs have two or even three of the above rotation angles among their twelve rotation angles.

\section{Angles between preferred $c$-Axis orientations in a multi-maximum fabric}

In Figure 3, the strongest concentration in $\gamma$ can be seen around $40^{\circ}, c .50^{\circ}$, and $140^{\circ}$. It should be noticed that many of adjoining crystals in a multi-maximum fabric are in a very limited relation of this kind between $\tau$ and $\gamma$. Examination was then made of the data on this fabric reported in many other glaciers. Figure 4 shows the frequency of every angle between preferred $c$-axis orientations in this fabric. An outstanding peak can be seen when $\gamma$ is between 


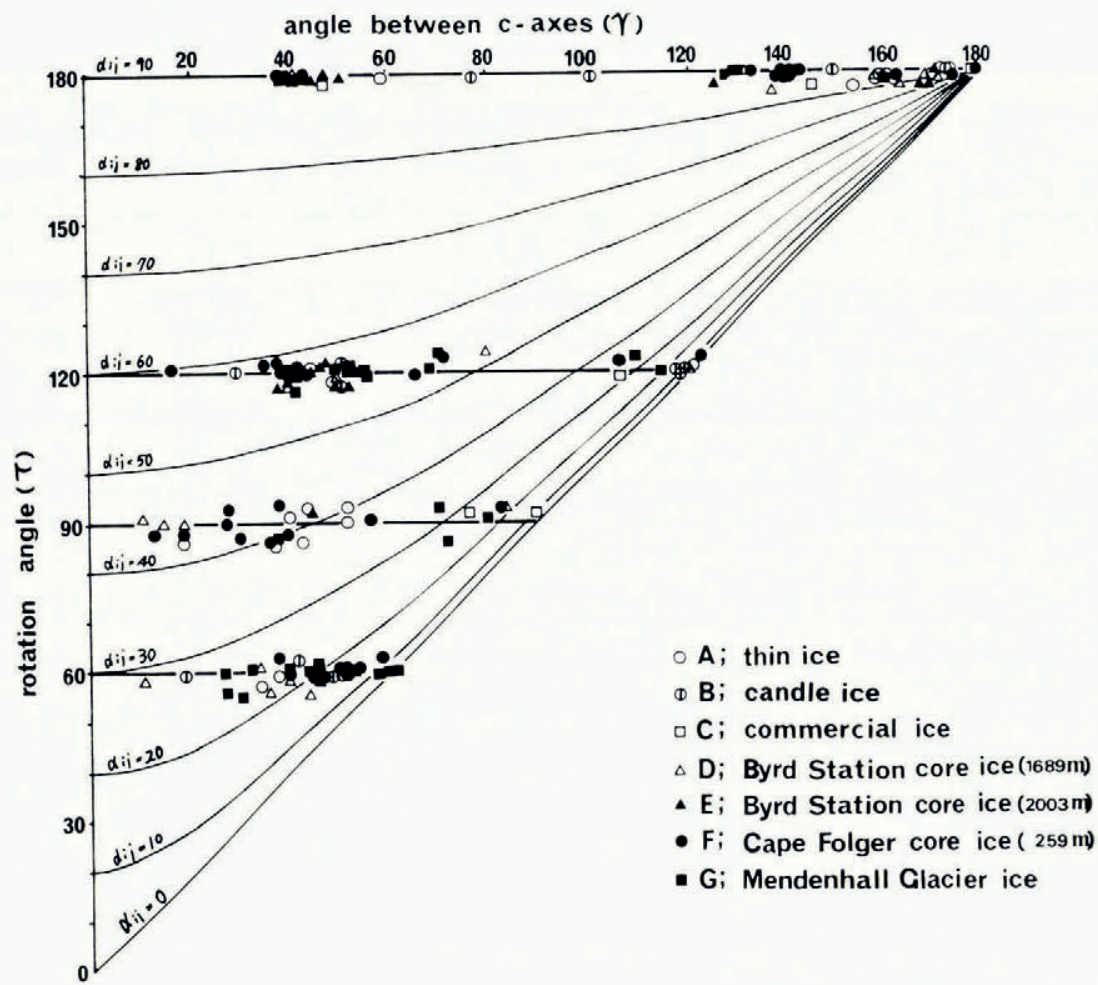

Fig. 3. Relation among $\gamma, \alpha_{i j}$, and $\tau$ obtained from Equation ( $\left.I\right)$. A pair of adjoining crystals are represented by one point.

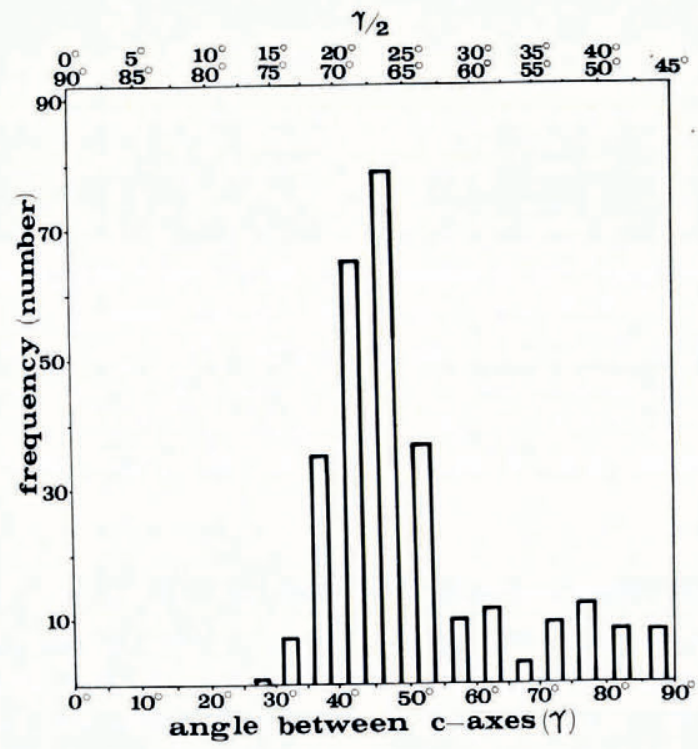

Fig. 4. Frequency histogram of the angle between peaks of preferred c-axis orientations of the multi-maximum fabrics found and reported in many glaciers and ice sheets over the world. 
$40^{\circ}$ and $50^{\circ}\left(130^{\circ}\right.$ and $\left.140^{\circ}\right)$. A good agreement is found with the $\gamma$ from the above-measured data of adjoining crystals, especially those related to each other by a $180^{\circ}$-rotation. This suggests that most of multi-maximum $c$-axis preferred orientations in each fabric may result from the same relation of a $180^{\circ}$-rotation between adjoining crystals. It is also suggested from this fact that the angles $\gamma=45^{\circ}$ and I $35^{\circ}$ would be the special angles related to a boundary between adjoining crystals.

\section{OXYGEN-OXYGEN BOND LINES}

A single crystal of ice has seven orientations of oxygen-oxygen lines (O-O lines) linked by a hydrogen bond. If one $\mathrm{O}-\mathrm{O}$ line coincides in orientation between adjoining crystals, the following equation can be derived using spherical trigonometry:

$$
\frac{\cos ^{2} 109 \cdot 5^{\circ}}{\cos ^{2} \gamma / 2}+\sin ^{2} 109.5^{\circ} \cos ^{2}\left(\alpha_{i j}-30^{\circ}\right)=\mathrm{I},
$$

where $0 \leqslant \frac{1}{2} \gamma \leqslant 70.5^{\circ}$. Since the tetrahedral angle (oxygen-oxygen-oxygen angle) in a crystal structure of ice is $109.5^{\circ}$, when $\frac{1}{2} \gamma>70.5^{\circ}$, these adjoining crystals cannot have such a coincident orientation of an $\mathrm{O}-\mathrm{O}$ line lying on the op plane (Fig. 2) which bisects the orientations of two $c$-axes. If two $\mathrm{O}-\mathrm{O}$ lines coincide in orientation between adjoining crystals,

$$
\frac{1}{2} \gamma=22.5^{\circ} \text { or } 67.5^{\circ}, \quad \alpha_{i j}=30^{\circ}, 90^{\circ} \text {, and } \mathrm{I}_{5} \mathrm{o}^{\circ} \text {. }
$$

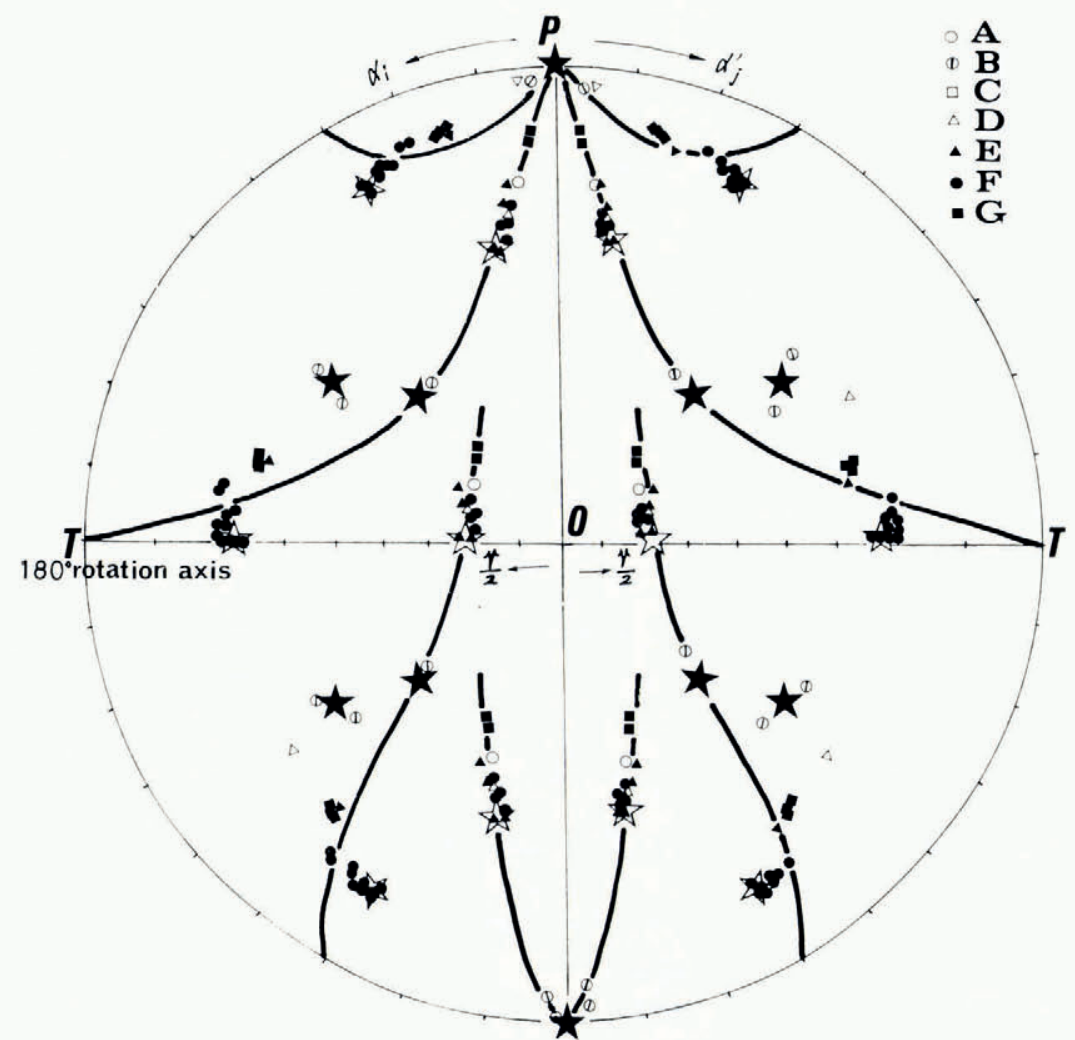

Fig. 5. Orientations of three a-axes, plotted on a Wulff net, of each crystal in the relation of $(180 \pm 2)^{\circ}$ rotational symmetry with its adjoining crystal. Rotation axis is fixed at T. Solid lines show loci (cf. Equation (2)) of a-axes of the crystal which has one coincident orientation of an $\mathrm{O}-\mathrm{O}$ line on $\mathrm{PO}$ plane (mirror plane) with its adjoining crystal. Open stars show the a-axis orientations of the crystal having two coincident $O-O$ lines, solid stars representing those of the crystal having four coincident $\mathrm{O}-\mathrm{O}$ lines. 
If four O-O lines coincide,

$$
\frac{1}{2} \gamma=35.2^{\circ} \text { or } 54.8^{\circ}, \quad \alpha_{i j}=0^{\circ}, 60^{\circ} \text {, and } 120^{\circ} .
$$

It is geometrically obvious that three, or more than four, coincident $\mathrm{O}-\mathrm{O}$ lines cannot exist between adjoining crystals.

The existence of a coincident orientation of an $\mathrm{O}-\mathrm{O}$ line always brings adjoining crystals into the relation of a $180^{\circ}$-rotation (equivalent to a mirror reflection), so $\alpha_{i}=\alpha_{j}^{\prime}=\alpha_{i j}$. In this connection, the existence of the coincident orientation of an O-O line was examined for all the measured pairs of adjoining crystals which are in the relation of $0 \leqslant \frac{1}{2} \gamma \leqslant 70.5^{\circ}$ and $\alpha_{i} \approx \alpha_{j}^{\prime}$.

In Figure 5 (angle-true Wulff net), the $\mathrm{I} 80^{\circ}$-rotation axis is fixed at $\mathrm{T}$ and three $a$-axes are plotted so that the $c$-axis is on the To plane at the position of a $180^{\circ}$ rotation with respect to the rotation axis T. The curves of solid lines are the loci of $a$-axes, drawn on the basis of Equation (2). A good agreement can be seen between the measured and geometrically derived $a$-axis orientations. Thus, most of the adjoining crystals related by a $180^{\circ}$ rotation have at least one coincident orientation of an O-O line on the op plane, which is perpendicular to the rotation axis. All the foregoing facts suggest that the existence of a coincident $\mathrm{O}-\mathrm{O}$ line may connect adjoining crystals very closely.

In Figure 5 , notable concentrations can be seen in the $a$-axis orientations (open stars) of a crystal having two coincident $\mathrm{O}-\mathrm{O}$ lines with its adjoining crystal $\left(\frac{1}{2} \gamma=22.5^{\circ}\right.$ and $\left.67.5^{\circ}\right)$.

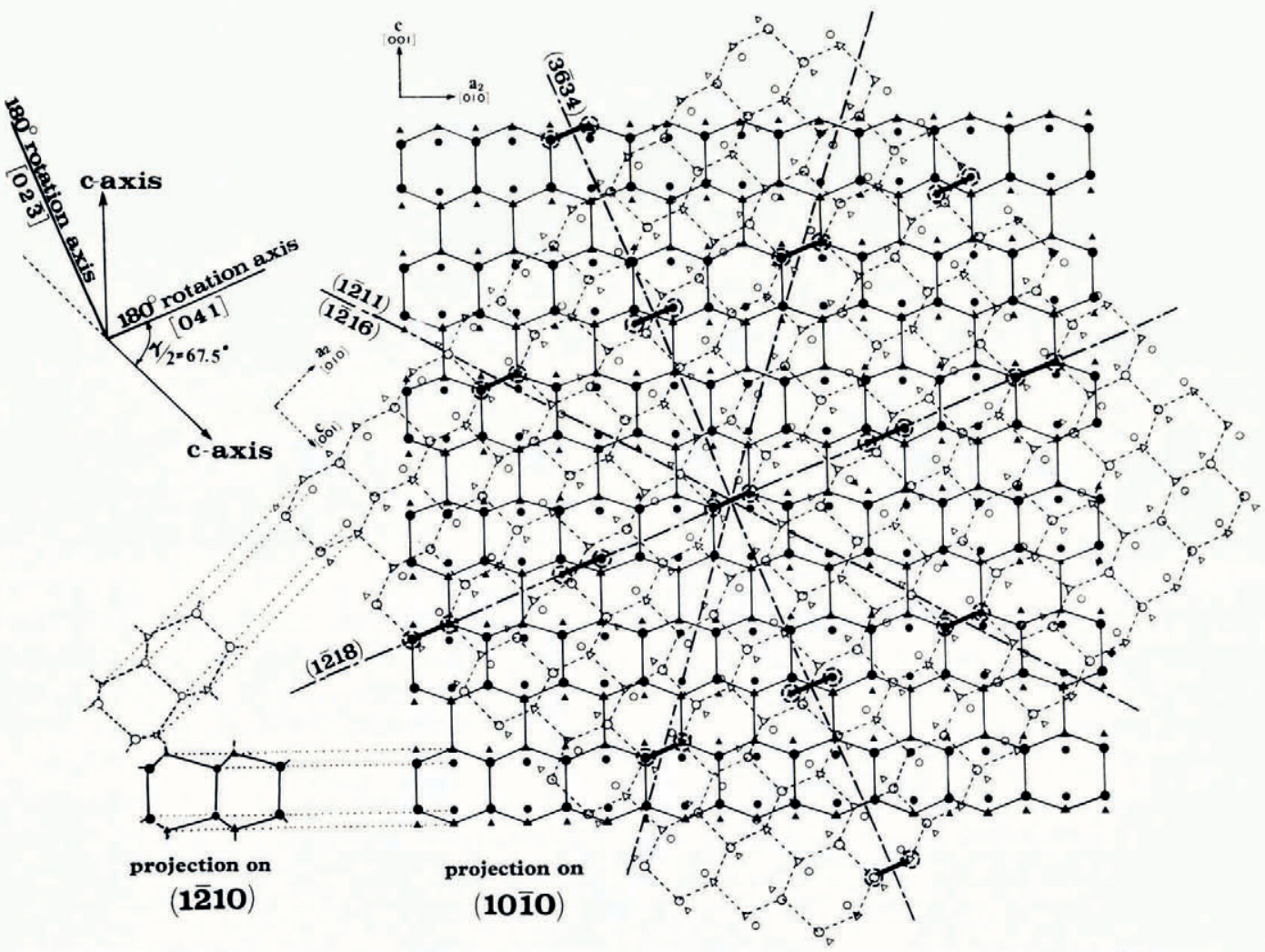

Fig. 6. Model of the boundary structure, projected onto $(\mathrm{I} O \overline{\mathrm{I}} \mathrm{O})$, of $\frac{1}{2} \gamma=22.5^{\circ}$ and $67.5^{\circ}$ at which one crystal (oxygen atoms are indicated by solid symbols; $O-O$ lines by solid lines) approaches its adjoining crystal (oxygen atoms by open symbols; $\mathrm{O}-\mathrm{O}$ lines by dashed lines). Coincident positions of the oxygen atoms are indicated by dashed circles, coincident orientations of $\mathrm{O}-\mathrm{O}$ lines being indicated by thick solid lines. 
This concentration is especially noted for a Cape Folger core ice (F), which shows the most conspicuous multi-maximum "diamond" fabric. Meanwhile, at $\frac{1}{2} \gamma=35.2^{\circ}$ and $54.8^{\circ}$, where four coincident $\mathrm{O}-\mathrm{O}$ lines exist, no peculiarity can be recognized except for the candle ice (в) grown from the melt. However, this angle is found in the plane assemblages of both the spatial and the radiating types of snow crystals (Lee, I972; Uyeda, unpublished; Kobayashi and others, 1976). Such a difference, in crystallographic relations between a snow crystal, ice grown from the melt, and glacier ice may be attributed to the difference in the conditions of crystal growth, namely, crystal growth from the vapour, melt, or solid phase.

\section{Boundary STRUCture of A MUlti-MaXimum FABric}

The values $\frac{1}{2} \gamma=22.5^{\circ}$ and $67.5^{\circ}$ may thus be singular angles in a polycrystalline glacier ice under a possibly thermodynamic sub-stable state. So, the boundary structure at these angles was examined. Figure 6 shows two lattice structures of ice which are superimposed so that their lattice orientations make this singular angle with each other. A regular period can be seen in the coincident orientations of an $\mathrm{O}-\mathrm{O}$ line (indicated by thick lines) and also in the coincident positions of oxygen atoms (surrounded by dashed circles). Several planes on which their periodic coincidence occurs with high density are found. Their planes are of low plane indices as indicated in Figure 6 (indices of $180^{\circ}$-rotation axes are also indicated in Figure 6). This implies that the adjoining crystals in a multi-maximum fabric could approach one another very closely along either of these low-index planes.

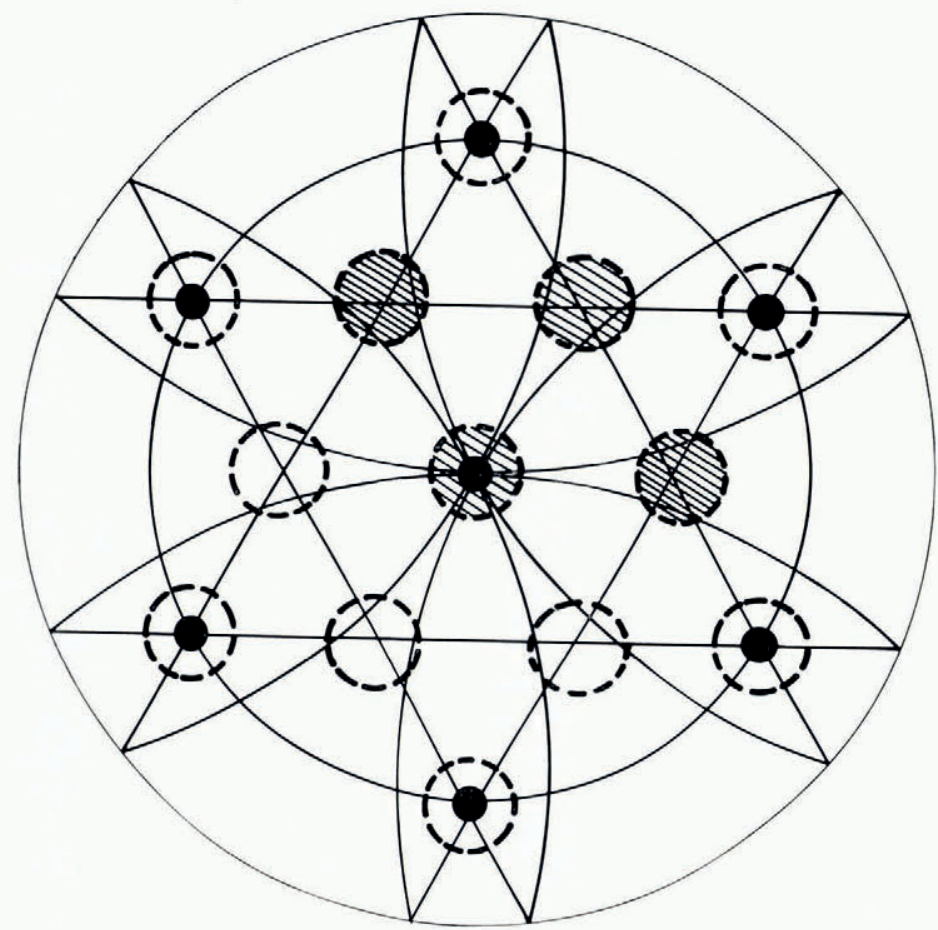

Fig. 7. Orientations of seven $O$ - $O$ lines (solid circles) of a single crystal of ice, the c-axis of which is at the centre of the Wulff net. Solid lines are loci of the orientation with which each of the seven $\mathrm{O}-\mathrm{O}$ lines makes the tetrahedral angle, Iog. $5^{\circ}$. Dashed and shaded circles show the areas where several intersections of the loci concentrate. 


\section{Coincident O-O Line Fabric}

Figure 7 shows the seven orientations of an O-O line of a single crystal of ice (solid circles). The solid lines are the loci of the orientations with which each of the seven $\mathrm{O}-\mathrm{O}$ lines (solid circles) makes the tetrahedral angle of $\mathrm{r} 09 \cdot 5^{\circ}$ (O-O-O angle). If coincident orientations of an O-O line exist in both this single crystal (in Fig. 7) and its adjoining crystal, the $c$-axis orientation of the adjoining crystal must be somewhere on the locus. Accordingly, if the $c$-axes of adjoining crystals are concentrated in the directions where several intersections of loci are concentrated (surrounded by small dashed circles), their coincident $\mathrm{O}-\mathrm{O}$ lines with the single crystal can be concentrated in the orientations of seven $\mathrm{O}-\mathrm{O}$ lines of the single crystal (solid circles). The angles between small dashed circles are about $(45 \pm 5)^{\circ}$. This angle reveals a marked agreement with the measured angles between preferred $c$-axis orientations of the multi-maximum fabric, as shown in Figure 4 .

For all the measured adjoining crystals in each polycrystalline ice of different origin, the coincident orientations of $\mathrm{O}-\mathrm{O}$ lines were then examined. Their orientations were plotted on one and the same equal-area projection net (Fig. 8). It should be noted that these are highly

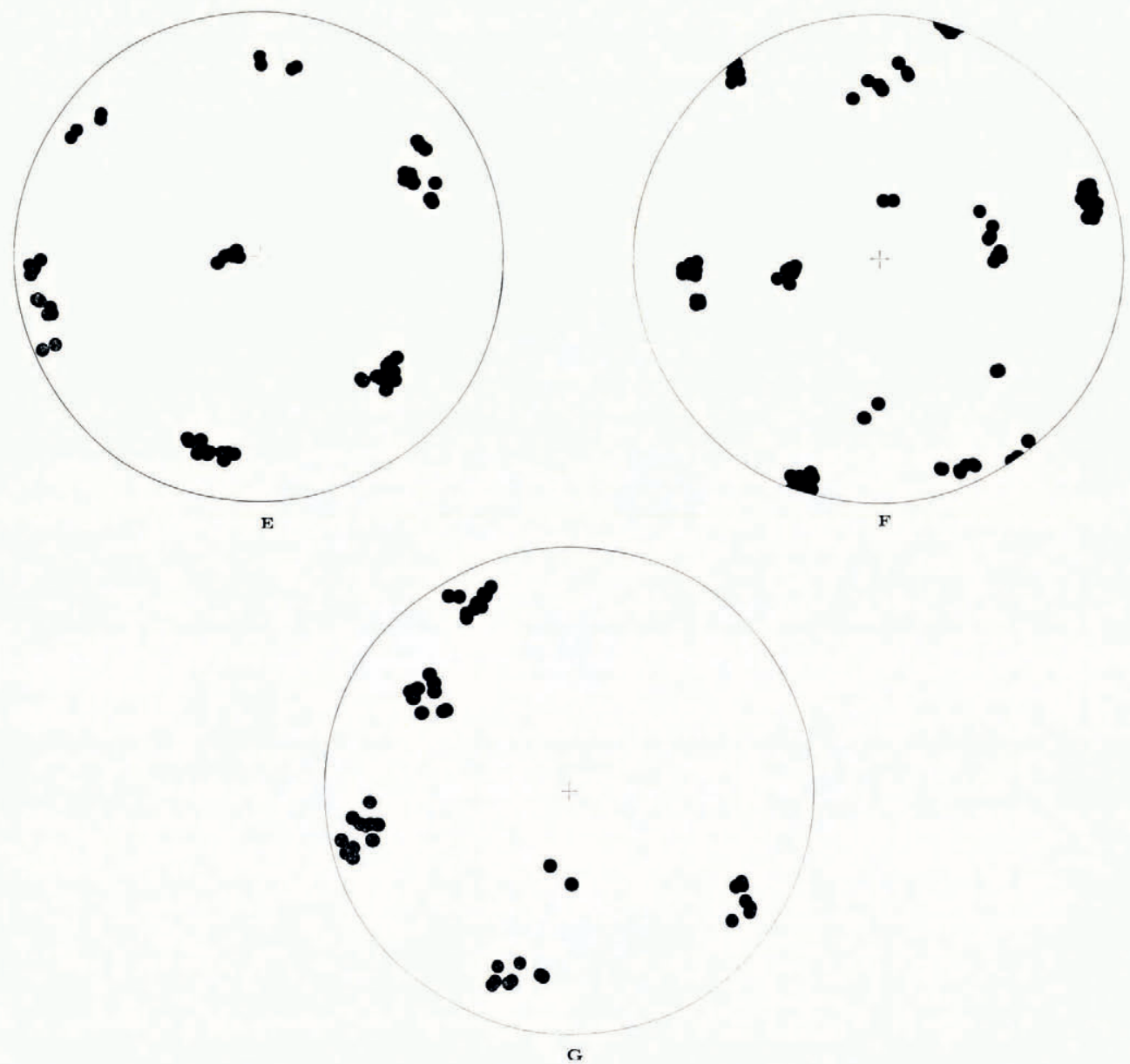

Fig. 8. Coincident $O-O$ line fabrics plotted on an equal-area Schmidt net. E: "Byrd" station core ice (20o3 $m$ deept), $F$ : Cape Folger core ice (259 $\mathrm{m}$ deep), G: Mendenhall Glacier ice. 
concentrated in several orientations and that their spatial distributions are very close to the seven orientations of $\mathrm{O}-\mathrm{O}$ lines of a single crystal of ice, as predicted above.

It was also found that a multi-maximum $c$-axis fabric (Cape Folger core ice, Mendenhall Glacier ice, and "Byrd" core ice) has more adjoining crystals related by a $180^{\circ}$ rotation than other $c$-axis fabrics such as a single-maximum fabric. These facts strongly suggest that a polycrystalline ice having a multi-maximum $c$-axis preferred orientation fabric (diamond pattern) has the closest crystallographic structure to the structure of a single crystal of ice.

\section{Concluding Remarks ANd Discussion}

For several types of polycrystalline ice of different origins, the spatial lattice orientation of a crystal was determined by measurements of both the $a$ - and $c$-axes. Analyses of orientations of adjoining crystals clarified that a great majority of the adjoining crystals may be in a twinning relation. This may suggest a strong possibility that the structural relation between crystals plays a major role in the appearance and growth of nuclei which have specific orientations during recrystallization.

Experiments on recrystallization are now in progress in Sapporo by K. Kitakizaki using the three-point bending method of deforming a single ice crystal. Data being obtained are confirming the above possibility. Orientations of nuclei of recrystallized crystals have specific relations with the orientations of their mother crystals and/or their adjoining crystals, the rotations being of the $60^{\circ}, 90^{\circ}$, $120^{\circ}$, or $180^{\circ}$ rotation symmetry. The detailed analytical results and their correlation with the measured results of glacier ice will be published.*

Most fabrics observed in glaciers and ice sheets such as single-maximum, two-maximum, and small-girdle fabrics, have been experimentally produced in the laboratory, while the formation of these fabrics has been explained by the basal sliding mechanism (Brace, I96o; Budd, I972; Kamb, I972). However, a multi-maximum "diamond" fabric has neither been successfully produced in the laboratory, nor has it been possible to explain the formation mechanism solely by basal sliding. It is also unlikely that non-basal sliding, boundary sliding, and self-diffusion, which have been observed in plastic deformation of ice (Shumskiy, I958; Nakaya, I958; Rigsby, ı960; Wakahama, ı960, I962, г964, I965; Gold, I963; Higashi and others, I968; Mae, I968; Barnes and others, I97I; and others), can explain the multi-maximum preferred orientations.

In addition to the foregoing mechanisms, another important mechanism which is normally found in metal deformation, is mechanical twinning, although it has never been reported for ice; i.e. neither have direct observations been made, nor has a theory been proposed to date for mechanical twinning of ice. Both sliding and twinning deformations are essentially caused by shear, while a twinning deformation in metal needs a much higher shear stress than sliding deformation. It is also found in metal that a twinning deformation proceeds by process of twin nucleation and propagation of a twin boundary (twin growth). Twin nucleation requires a very high shear stress, which would be provided by a local stress concentration due to nonbasal sliding. After twin nucleation breaks out, a much lower shear stress suffices for its propagation and growth, although it is still a higher stress than that for sliding deformation (Bell and Cahn, 1957). These observations obtained for twin deformation in metals give rise to the possibility that the multi-maximum "diamond" fabric of ice may be attributable to mechanical twinning. The multi-maximum fabric has the following characteristics: it is composed of crystals in very specific lattice orientations, which form a polycrystalline structure close to the structure of a single crystal of ice; many of the crystal boundaries are twin boundaries of a very specific lattice structure, as shown in Figure 5; the crystal size in this fabric is larger than in any other fabrics; the degree of elongation of bubbles contained is very

* Paper in preparation by M. Matsuda and K. Kitakizaki. 
small and the bubbles are rather spherical; this fabric has been found in those parts which have undergone a very strong shear deformation at a temperature relatively close to the melting point. Matsuda and Wakahama* found that this fabric exists in a stable state at those parts of the glacier where an octahedral shear stress exceeds about 0.4 bar (other fabrics are stable under a lower shear stress). Plastic deformation of the ice with this fabric must be thus due to a deformation mechanism that preserves the above characteristics of this fabric despite a large plastic deformation. Hence, mechanical twinning may be a possible, even a likely mechanism to satisfy this condition. This is because absorption of a large amount of plastic strain energy produced by such a strong shear stress can be made by the propagation of twin boundaries without changing the relative structural relation between crystals, without changing a crystal boundary structure, and without making strong bubble elongation.

The more detailed mechanism of fabric formation and its quantitative relations with stress and stress configuration are described by Matsuda and Wakahama.*

\section{Acknowledgments}

This study started from the analysis of the Cape Folger core ice drilled in 1969 by ANARE as part of its project led by Dr W. F. Budd of Antarctic Division, Australia. The authors would like first to express their sincere gratitude to him for providing an opportunity to pursue this study and for many suggestions and encouragement. They are also grateful to Professor A. Higashi, leader of the third Hokkaido University Alaska Glacier Expedition, as well as, to their colleagues of this expedition to Mendenhall Glacier for offering useful suggestions and making ice samples available. They are much indebted to Professor C. C. Langway, jr., New York State University, through whom the "Byrd" station ice cores were provided to the Institute of Low Temperature Science, Hokkaido University; their physico-chemical properties are now under analysis by a research group of the Institute (leader Professor D. Kuroiwa), part of the analytical results of which is included in the present paper. In conclusion, they must thank Professor K. Kizaki, Ryukyu University, for his personal inspiration, which has helped make this study possible.

\section{REFERENCES}

Barnes, P., and others. 1971. The friction and creep of polycrystalline ice, by P. Barnes, D. Tabor and J. C. F. Walker. Proceedings of the Royal Society of London, Ser. A, Vol. 324, No. 1557, p. 127-55.

Bell, R. L., and Cahn, R. W. r957. The dynamics of twinning and the interrelation of slip and twinning in zinc crystals. Proceedings of the Royal Society of London, Ser. A, Vol. 239, No. 12 19, p. 494-52 1.

Brace, W. F. 1960. Orientation of anisotropic minerals in a stress field: discussion. Geological Society of America. Memoir 79, p. 9-20.

Budd, W. F. 1972. The development of crystal orientation fabrics in moving ice. Zeitschrift für Gletscherkunde und Glazialgeologie, Bd. 8, Ht. 1-2, p. 65-105.

Budd, W. F., and Matsuda, M. I974. Nijiku-kuriipu asshuku ni okeru takesshōhyō no sentaku-hōisei ni tsuite [On preferred orientation of polycrystalline ice by biaxial creep]. Teion-kagaku: Low Temperature Science, Ser. A, [No.] 32, p. $26 \mathrm{I}-65$.

Endō, Y. 197I. Gansetsu o fukumu hyōgahyō no kōzō to soshiki [Structure and texture of glacier ice containing rock fragments]. Teion-kagaku: Low Temperature Science, Ser. A, [No.] 29, p. 176-84.

Gold, L. W. 1963. Deformation mechanism of ice. (In Kingery, W. D., ed. Ice and snow; properties, processes, and applications: proceedings of a conference held at the Massachusetts Institute of Technology, February I2-16, 1962. Cambridge, Mass., M.I.T. Press, p. 8-27.)

Gow, A. J. 1970. Deep core studies of the crystal structure and fabrics of Antarctic glacier ice. U.S. Cold Regions Research and Engineering Laboratory. Research Report 282.

Higashi, A. 1967. Ice crystal growth in a temperate glacier in Alaska. (In Ōura, H., ed. Physics of snow and ice: international conference on low temperature science. . . . 1966. . . Proceedings, Vol. I, Pt. I. [Sapporo], Institute of Low Temperature Science, Hokkaido University, p. 409-3o.)

* Paper in preparation by M. Matsuda and G. Wakahama entitled "Ice fabric phases and their plastic deformation mechanisms in glaciers and ice sheets. 
Higashi, A., and others. 1968. Strength of ice single crystals in relation to the dislocation structure, by A. Higashi, M. Oguro and A. Fukuda. (In Proceedings of the international conference on the strength of metals and alloys, September 1967, Tokyo, Japan. Tokyo, Japan Institute of Metals, p. 784-89. (Transactions. Japan Institute of Metals, Vol. 9, Supplement.))

Hooke, R. L. I973. Structure and flow in the margin of the Barnes Ice Cap, Baffin Island, N.W.T., Canada. Journal of Glaciology, Vol. 12, No. 66, p. 423-38.

International Union of Crystallography. 1959. International tables for X-ray crvstallography. Vol. 2. Mathematical tables. Birmingham, Kynoch Press.

Jonsson, S. 1970. Structural studies of subpolar glacier ice. Geografiska Annaler, Vol. 52A, No. 2, p. 129-45.

Kamb, W. B. 1959[a]. Ice petrofabric observations from Blue Glacier, Washington, in relation to theory and experiment. Journal of Geophysical Research, Vol. 64, No. i i, p. 1891-909.

Kamb, W. B. 1959[b]. Theory of preferred crystal orientation developed under stress. Journal of Geology, Vol. 67 , No. 2 , p. ${ }^{1} 53-70$.

Kamb, W. B. 1972. Experimental recrystallization of ice under stress. (In Heard, H. C., and others, ed. Flow and fracture of rocks, edited by H. C. Heard, I. Y. Borg, N. L. Carter and C. B. Raleigh. Washington, D.C., American Geophysical Union, p. 21 I-4I. (Geophysical Monograph I6.))

Kizaki, K. I 962 . Icefabric studies on Hamna Ice Fall and Honhörbrygga glacier, Antarctica. Nankyoku Shiryō: Antarctic Record, [No.] 16, p. 54-74.

Kizaki, K. I969[a]. Fabric analysis of surface ice near Casey Range, east Antarctica. Journal of Glaciology, Vol. 8, No. 54, p. $375-83$.

Kizaki, K. r 969 [b]. Ice-fabric study of the Mawson region, east Antarctica. Journal of Glaciology, Vol. 8, No. 53, p. $253-76$.

Kizaki, K. 1974. Ice fabrics no kenkyūshi to sono mondaiten [History and problems of ice fabric studies]. (In Kuroiwa, D., ed. Kyokuchi hyōshōhyō no butsuriteki kagakuteki kenkyū [Physical and chemical studies on ices [sic] from glaciers and ice sheets]. Monbushō Kagaku Kenpi Sōgō Kenkyū (A). Hokokusho, [1973], p. 85-93.)

Kobayashi, T., and others. I976. Cubic structure models at the junctions in polycrystalline snow crystals, [by] T. Kobayashi, Y. Furukawa and T. Takahashi. Journal of Crystal Growth, Vol. 35, No. 3, p. 262-68.

Kumazawa, M. 1963. A fundamental thermodynamic theory on nonhydrostatic field and on the stability of mineral orientation and phase equilibrium. Journal of Earth Sciences, Nagoya University, Vol. I I, No. 2, p. $145-217$.

Lee, C. W. 1972. On the crystallographic orientation of spatial branches in natural polycrystalline snow crystals. Fournal of the Meteorological Society of Japan, Vol. 50, No. 3, p. i 7 I-80.

MacDonald, G. J. F. 1960 . Orientation of anisotropic minerals in a stress field. Geological Society of America. Memoir 79, p. I-8.

Mae, S. r 968 . Void formation during non-basal glide in ice single crystals under tension. Philosophical Magazine, Eighth Ser., Vol. 18, No. 151, p. 101-14.

Matsuda, M., and others. I 9776 . Nankyokuhyōshōhyō no sōshō. Hyōkesshō a-jiku no sokutei ni motozuku daiyamondo-patān no keisei ni tsuite [Twinning of ice from Antarctic ice sheet. Observations of $a$-axis orientation associated with diamond $c$-axis orientation fabric]. [By] M. Matsuda, G. Wakahama, W. F. Budd. Teion-kagaku: Low Temperature Science, Ser. A, [No.] 34, p. 163-71.

Nakaya, U. 1958. Mechanical properties of single crystals of ice. Pt. I. Geometry of deformation. U.S. Snow, Ice and Permafrost Establishment. Research Report 28.

Reid, J. R. 1964. Structural glaciology of a firn fold, Antarctica. (In Mellor, M., ed. Antarctic snow and ice studies. Washington, D.C., American Geophysical Union, p. 237-66. (Antarctic Research Series, Vol. 2.))

Rigsby, G. P. 1951. Crystal fabric studies on Emmons Glacier, Mount Rainier, Washington. Fournal of Geology, Vol. 59 , No. 6, p. $590-98$.

Rigsby, G. P. 1960. Crystal orientation in glacier and in experimentally deformed ice. Journal of Glaciology, Vol. 3 , No. 27 , p. $589-606$.

Rigsby, G. P. 1968. The complexities of the three-dimensional shape of individual crystals in glacier ice. Journal of Glaciology, Vol. 7, No. 50, p. 233-51.

Shumskiy, P. A. 1958. The mechanism of ice straining and its recrystallization. Union Géodésique et Géophysique Internationale. Association Internationale d'Hydrologie Scientifique. Symposium de Chamonix, I6-24 sept. 1958, p. $244-48$. (Publication No. 47 de l'Association Internationale d'Hydrologie Scientifique.)

Tanaka, H. 1972. On preferred orientation of glacier ice and experimentally deformed ice. Journal of the Geological Society of Japan, Vol. 78, No. 12, p. 659-75.

Taylor, L. D. 1963 . Structure and fabric on the Burroughs Glacier, south-east Alaska. Journal of Glaciology, Vol. 4 , No. 36 , p. $73 \mathrm{I}-52$.

Uyeda [i.e. Ueda], H. Unpublished. Takesshō-gata yukikesshō to tōketsu suiteki no kesshō shūsei ni tsuite [On crystal habits of polycrystalline snow crystals and frozen droplets]. [M.Sc. thesis, Hokkaido University, I975.]

Vallon, M., and others. 1976. Study of an ice core to the bedrock in the accumulation zone of an Alpine glacier, by M. Vallon, J.-R. Petit and B. Fabre. Fournal of Glaciology, Vol. 1 7, No. 75, p. 13-28.

Wakahama, G. I960. Sekisetsu no hakuhen o ōyo shita sekisetsu no soshiki to naibu-hizumi no kenkyū. I. - II [Internal strain and changes in the microscopic texture of ice caused by compression. I.-II]. Teion-kagaku: Low Temperature Science, Ser. A, [No.] I 9, p. 37-96.

Wakahama, G. I962. Kōri no sosei henkei ni tsuite. I.-IV [On the plastic deformation of ice. I.-IV]. Teionkagaku: Low Temperature Science, Ser. A, [No.] 20, p. 57-1 30.

Wakahama, G. I964. Kōri no sosei henkei ni tsuite. V. Takesshōhyō no sosei henkei [On the plastic deformation of ice. V. Plastic deformation of polycrystalline ice]. Teion-kagaku: Low Temperature Science, Ser. A, [No.] 22, p. $1-24$. 
Wakahama, G. 1965. Kōri no naibu hakai ni tsuite [Internal fracture of ice]. Teion-kagaku: Low Temperature Science, Ser. A, [No.] 23, p. 39-50.

Watanabe, O., and Ōura, H. 1968. Hen atsu ni yoru kōri kesshō shujiku no teihōisei ni tsuite no jikkenteki kenkyū. I [Experimental studies of preferred orientation of polycrystalline ice by unconfined compression. I]. Teion-kagaku: Low Temperature Science, Ser. A, [No.] 26, p. I-28.

\section{DISCUSSION}

W. B. Kамв: Perhaps I should point out that I have been measuring $a$-axis orientations in temperate glacier ice for 5 years and have much unpublished data of this kind. In agreement with what you find, my data show strong $a$-axis fabrics in many cases.

J. W. GLEN : I realize that you are reporting results and may not be in a position to indicate yet the reason for them, but the formation of these fabrics during original growth seems unlikely in some of these cases. The appearance of very specific orientation relations in recrystallization and grain growth might be due to preferred growth in certain orientations, or to the relative inability to eliminate a boundary with lower energy, or structural relations between grains. Do you have any ideas on this at the present stage?

M. Matsuda: At least in the appearance of nuclei which have specific orientations, their structural relation with their mother crystals and/or their adjoining crystals is to play a major role. For both experimentally recrystallized ice and glacier ice, clear regularity was found in the structural relations between adjoining crystals. Such a structural relation is of great importance for nucleation taking place during recrystallization. However, the formation of specific preferred orientation fabrics observed in bulk glacier ice which is undergoing constant plastic deformation, would be largely dependent on the deformation mechanism, which varies with stress and temperature.

Although relative inability to eliminate a boundary with lower energy may contribute to the formation of a conspicuous preferred orientation fabric, it is expected to play a rather minor role in the appearance of specific preferred orientations. 